\title{
Telas construidas o cómo las palabras referidas a tejidos se instalan en el léxico de la arquitectura ${ }^{1}$
}

\author{
Constructed Fabrics, or How Words Referring to Fabrics are Incorporated into \\ the Lexicon of Architecture
}

\author{
Dolores Serrano-Niza \\ Universidad de La Laguna \\ http:/ / orcid.org/0000-0001-6296-4786 \\ dserrano@ull.edu.es
}

Recibido: 30/06/2020; Revisado: 04/08/2020; Aceptado: 22/10/2020

\begin{abstract}
Resumen
En este trabajo se analiza el trasvase que se produce desde el léxico de los tejidos hasta el de la arquitectura. Para ello se estudia la estrecha relación histórica que ha existido entre uno y otro campo técnico y se explican las razones semánticas causantes de dicho trasvase. La investigación se enmarca en la línea cronológica que va desde el siglo XIII al XVI y en una zona geográfica concreta, la zona meridional de la península ibérica; un tiempo y un espacio de gran interés histórico y lingüístico para el objetivo planteado. Tras examinar cómo eran y qué funcionalidad tenían ciertos tejidos pertenecientes al mobiliario doméstico, se analizan aquellas palabras de origen árabe que ahora pertenecen al vocabulario de la arquitectura.
\end{abstract}

Palabras clave: Espacio doméstico, textiles, arabismos, Edad Media, península ibérica.

\begin{abstract}
This article analyses the transfer that occurs between the lexicon of fabrics and that of architecture. As such, the article examines the close historical relationship between one technical field and the other, and explains the semantic reasons behind such transfer. The research is chronologically framed between the 13th to the 16th century, and geographically focused upon the southern part

1 Este trabajo se enmarca en el proyecto «Vestir la casa: espacios, objetos y emociones en los siglos XV y XVI» (VESCASEM), (Referencia: PGC2018-093835-B-100, financiado por FEDER/Ministerio de Ciencia e Innovación-Agencia Estatal de Investigación. IP: María Elena Díez Jorge.
\end{abstract}


Telas construidas o cómo las palabras referidas a tejidos se instalan en el léxico...

of the Iberian Peninsula, because these are a time and place of great historical and linguistic interest for the stated objective. After examining the nature and functionality of certain fabrics pertaining to home furnishings, analysis turns to those words of Arabic origin that now belong to the vocabulary of architecture.

Key words: Domestic Space, Textiles, Arabisms, Middle Ages, Iberian Peninsula.

\section{INTRODUCCIÓN}

Recientemente se celebró el XXII Congreso Nacional de Historia del Arte cuyo sugerente tema fue «Vestir la arquitectura». ${ }^{2}$ En efecto, la relación entre los textiles y la arquitectura no es ni mucho menos nueva en la historia, teniendo dicha relación muy diferentes direcciones, según el momento histórico y las circunstancias que se observen. Durante la Edad Media, por ejemplo, los tejidos fueron una parte esencial de los espacios interiores a los que aportaron una clara funcionalidad. Pero no sólo cumplían con una función determinada, a veces de «construcción» de la propia estancia, a modo de tabiques textiles, sino que también eran el ornato de las estancias. Esta última es la razón por la que, con el tiempo, esas telas acaban siendo pintadas en muros, «emulando su disposición, decoración e incluso texturas» (RoDRíguez, 2019:108). Uno de tantos ejemplos de esta afirmación, lo recoge María Angélica MarTínez (2019: 177) quien expone cómo ciertos edificios del México virreinal muestran una clara imitación de patrones textiles, transformados estos en «fuente de inspiración para los adornos arquitectónicos». ${ }^{3}$ Asimismo, y ya en España, tenemos ejemplos en los que la textura del terciopelo recaló en territorios pétreos, como se expone en «Del terciopelo a la piedra: tejidos simulados, heráldica y memoria en el colegio de San Gregorio de Valladolid» (Olivares, 2019: 101-107). Es decir, lo que parece es que el valor, en su sentido amplio, que los tejidos tenían en los espacios domésticos es la explicación por la que, y en palabras de Juan Carlos Ruiz (2014: 760) «su aspecto quisiera ser simulado en las artes y muy especialmente en la arquitectura».

De hecho, entre los objetivos de este trabajo se encuentra el de querer profundizar en esta relación más que consumada entre los textiles y la arquitectura, un estudio que se abordará a través del léxico. Bien es verdad que no es la primera vez que un trabajo científico aborda el análisis del trasvase de vocabulario que participa de ciertas peculiaridades, como el que se produce entre un léxico propio de los tejidos y su recepción en el de la arquitectura. Otros estudios que preceden a este ya se han percatado, de una u otra manera, de este hecho. En un caso, se han ocupado exclusivamente de las palabras y su definición, poniendo el punto de interés en la técnica misma, como es el caso del estudio realizado por María NúÑEZ-GONZÁLEZ «Domestic Architecture in 16th Century Seville: San Salvador», o el de Antonio OrinuelA, «Técnicas constructivas en la arquitectura doméstica de los moriscos granadinos».

2 Los resultados de dicho congreso se han publicado en PAYO et al. (2019). Quisiera aprovechar esta ocasión para agradecer a la profesora Rodríguez Peinado su amabilidad al enviarme alguno de los trabajos en él publicados de imposible consulta durante el periodo de confinamiento vivido recientemente en España y cuya lectura enriquece, sin duda alguna, estas páginas.

3 Agradezco a la autora su texto original de este trabajo que ha sido de gran ayuda para el mío. 
En otros casos, en cambio, lo que ha prevalecido ha sido la estrechísima relación existente entre telas y arquitectura, como pone de relieve el trabajo de Juan Carlos Ruiz (2014: 497-516). Pero todos ellos tienen en común una línea cronológica, la que arranca en el siglo XIII y se detiene en el XVI. Un trazado temporal que voy a tomar para enmarcar mi propio trabajo y, al que ahora, añado un acotamiento espacial. En este caso, me centraré en el estudio del ámbito doméstico de aquellas casas ubicadas en tierra islámica dentro de una península ibérica que, paulatinamente, iba convirtiéndose en cristiana, lo que, en consecuencia, reduce mi estudio a la zona meridional peninsular. Y, así, con estas coordenadas espaciales y temporales, pretendo aunar los objetivos de los trabajos que me preceden. Es decir, mi propósito es analizar cómo eran y qué funcionalidad tenían esos tejidos que formaban parte del mobiliario doméstico, con el fin de estudiar el trasvase terminológico de un campo semántico al otro, ocupándome, principalmente, de aquellas palabras cuyo étimo sea de origen árabe. Esta elección proviene, básicamente, del interés que tiene el acervo cultural que la larga convivencia entre el mundo islámico y el cristiano tuvo en la península ibérica.

En este sentido, la historia y con ella una extensa bibliografía científica, ya han dado cuenta de los intensos intercambios culturales consolidados, sobre todo, a partir de que los reyes castellanos Fernando III (1199-1252) y Alfonso x (12211284) lograran estabilizar una frontera, la que separaba -y al mismo tiempo uníael reino de Castilla y el reino nazarí de Granada. Esa división territorial oscilante durante décadas representaba la clara oposición política y religiosa en la que cada una de las respectivas comunidades se situaba. En cambio, en lo estrictamente social, se podría decir que esa frontera actuaba a modo de espejo, un objeto en el que mirarse y mirar a un «otro" y en el que reafirmar la propia identidad. En cualquier caso, se podría considerar que la citada frontera castellano-nazarí podría muy bien haberse denominado «frontera de influencias» dado que durante siglos funcionó a modo de espacio permeable de trasvase cultural y recíproco enriquecimiento.

Las pruebas de esa transferencia cultural son muchas y uno de los ejemplos de ellas se encuentra en el modo de habitar una casa o de vestirse. Me refiero con esto a que, a lo largo de esos siglos, se fueron filtrando las costumbres más cotidianas, las que se trasvasan de persona a persona, quizás comenzando por la fascinación que los cristianos sintieron por sus vecinos musulmanes hasta convertir esa atracción en imitación y, así, el gusto por lo oriental se instaló en su cotidianidad dando lugar a la emulación que culminaría en una forma de vivir o de vestirse muy semejante. De esta manera, telas, ropas, calzados, tocados, técnicas textiles, mobiliario, entre otros, característicos de los andalusíes fueron ocupando un espacio propio en las casas y guardarropas castellanos, produciéndose así una original moda sin parangón en el resto de la Europa medieval, ya que estaba surgiendo la denominada «moda española» (MARTínEZ, 2012:189). Bien es verdad que esta fascinación, aún existiendo, tuvo mucho de marca distintiva de las clases más privilegiadas y de ahí que podamos ver al rey Alfonso x sentado, a la morisca, entre «almadraques» y almohadones en una representación en las Cantigas, así como contemplar retratos de Isabel la Católica vistiendo una «alcandora» ${ }^{4}$ (GONZÁlEZ, 2014: 53).

4 Tipo de camisa morisca. 
Telas construidas o cómo las palabras referidas a tejidos se instalan en el léxico...

Lo cierto es que no tiene nada de excepcional el hecho de que dos comunidades en próxima convivencia durante un tiempo prolongado acaben compartiendo gestos cotidianos, ya sea por fascinación, ya sea por necesaria adaptación. Se verá, años después, cuando los moriscos convertidos en minoría empiecen a asumir costumbres castellanas, siendo, precisamente, la casa, con su mobiliario, su ajuar doméstico y las ropas de sus habitantes, el espacio donde mejor se puede rastrear aquellas pervivencias de origen islámico (Moreno, 2015:107-114).A la luz de los datos, en cualquier caso, parece no caber duda de que el estudio del espacio doméstico y todo lo que en él hay y habita, puede servir para comprender el pasado, involucrando en esta afirmación algunas de las vindicaciones de la microhistoria. En este caso concreto, además, con el estudio de los objetos, incluso, se podría profundizar en lo que APPADURAI (1986: 3-63) denomina «la vida social de las cosas», refiriéndose a cómo ciertos objetos son consumidos en un sentido u otro, por los diferentes estamentos de la sociedad o cómo ciertos objetos, hasta un determinado momento, poco valorados, adquieren un altísimo valor y viceversa. Cabría, en este contexto, preguntarse quién puso de moda qué y qué tipo de vinculación estableció cada sociedad con ciertos objetos. Esta indagación más profunda en aspectos relativos con la cultura material conduce a otro aspecto más que sustantivo en las presentes páginas. Me refiero no sólo al de la identificación de esos objetos sino, sobre todo, a las palabras que los nombran. Palabras, muchas veces desaparecidas ya de la lengua común o que permanecen con un significado distinto.

Por todo lo anterior, parece más que razonable considerar el estudio del espacio doméstico en su sentido más amplio como prueba testimonial de primer orden de esa encrucijada cultural relatada anteriormente. En ese estudio, los términos usados para nombrar las cosas son, además, otra prueba irrefutable, dado el elevado número de palabras que aparecen en el castellano (y en el resto de las lenguas peninsulares) y a las que se denomina «arabismos»; es decir, vocablos de origen árabe que forman parte de las lenguas romances de la península ibérica. $\mathrm{Su}$ estudio por campos conceptuales revela una presencia intensa en aspectos señalados de la vida cotidiana como, por ejemplo, la comida, la indumentaria, los enseres domésticos o, lo que aquí es un objetivo científico, los textiles.

Por lo tanto, y con el fin de alcanzar el objetivo propuesto, la metodología acometida ha sido la de realizar un vaciado lexicográfico de trabajos relevantes en el tema como son, por ejemplo, El vocabulario de Pedro de Alcalá, editado por Elena Pezzi, así como el Diccionario de arabismos y voces afines en iberorromance de Federico CORRIENTE y el Glossaire des mots espagnols et portugais dérivés de l'arabe de Dozy y Engelmann, a los que he sumado el indispensable Diccionario de Autoridades de la Real Academia Española. ${ }^{5}$ Este primer vaciado ha sido cotejado con otros referentes documentales donde esas palabras permanecen como huella testimonial de un momento histórico; me refiero a Inventarios de bienes moriscos del reino de Granada (siglo XVI) (MARTínez RuIZ, 1972). De un primer corpus extraído, y centrándome exclusivamente en los arabismos, he recuperado aquellos que

$5 \mathrm{~A}$ los trabajos mencionados se ha de añadir el Dictionnaire détaillé des noms des vêtements chez les arabes de Reinhart Dozy, muy útil en la búsqueda en textos árabes en las que aparece una descripción de los tejidos estudiados en este trabajo y de gran ayuda para establecer el étimo correcto de la palabra castellana. Asimismo, para este estudio ha sido crucial el Glosario elaborado por María Núñez-González en su trabajo Arquitectura, dibujo y léxico de alarifes en la Sevilla del siglo XVI cuya amabilidad al cederme la información cuando aún estaba inédita quisiera agradecer desde estas páginas. 
hacían referencia a textiles y de estos, los que tienen un significado propio dentro del lenguaje especializado de la arquitectura. Desde esta clasificación, se pondrá el foco en el estudio de las siguientes palabras: alcatifa, alicer, almatraya y acitara.

\section{LA PERMANENCIA DE LO EFÍMERO. TEXTILES QUE CONSTRUYEN Y AMUEBLAN}

Afirma Juan Carlos Ruız (2014: 498) que es imposible imaginar una Edad Media sin sus ricas telas y sus llamativos colores y, a juzgar por los restos de textiles conservados junto con los ejemplares rescatados de la pintura coetánea, en efecto, así es como habría que imaginar un interior doméstico. Sin embargo, y antes de avanzar en este aspecto concreto, hay que señalar muy sucintamente las singularidades que caracterizaron la industria textil medieval durante esa época, pues, en consonancia con lo expuesto hasta ahora hay ciertas peculiaridades que merecen la pena reseñar.

Por un lado, cuando los musulmanes entraron en la península ibérica en el siglo vIII hallaron una tradición manufacturera textil sencilla cuyas principales materias primas eran la lana, esencialmente, y también el lino y el esparto. Es decir, en esta época se desconocen el algodón y la seda como materias primas textiles. Aún así, hay que destacar que, si bien el arte textil peninsular conoce su auge gracias a la introducción de nuevas materias primas y técnicas textiles, su magnífico desarrollo se sustentó en una infraestructura previa que lo conformó. Sin ella «no se puede entender el auge de esta manufactura, basada en una compleja tecnología, quizás con las instalaciones más sofisticadas del entramado productivo de la sociedad andalusí» (RODRíGUEZ, 2012:265).

En cualquier caso, lo que sigue en cuanto a la industria textil en al-Ándalus fue un amplio perfeccionamiento del que dan cuenta las fuentes tanto cristianas como islámicas. En ese progreso de la manufactura, no sólo se integran el algodón, la seda y la lana marina ${ }^{6}$ como nuevas fibras textiles, sino que la industria tintorera camina de su mano para proveer de color y satisfacer su demanda en ropas y telas, no sólo porque tras ellos hubiera una moda sino porque el color representaba un valor añadido a los tejidos cuyo fin último era el comercio. Además de lo ya citado, se implementa la tecnología con diferentes tipos de telares y técnicas (SALADRIGAS, 1996: 88-98). En definitiva, la principal aportación a la producción textil peninsular que introducen los andalusíes es el uso de una tecnología mucho más sofisticada con la que obtener telas labradas de gran calidad. ${ }^{7}$ La excelencia que alcanzaron estas manufacturas textiles realizadas en al-Ándalus y conocidas, de manera general, como «tejidos hispanomusulmanes» (aunque más apropiado sería denominarlo «andalusíes») pueden ser todavía contempladas gracias al importante patrimonio conservado en nuestro país, aunque en estos casos se

6 Recibe este nombre el «biso» (byssus en latín), una fibra natural que se obtiene de los filamentos de ciertos moluscos y que daba lugar a un filamento muy fino, que tejido adquiere un tono dorado. El nombre de «biso» se extendió también para designar hilaturas de seda, lino o algodón cuando éstas eran muy delicadas. Con el biso se elaboraron textiles de gran calidad y lujo (LOMBARD, 1978:113-115). 7 Existen hallazgos arqueológicos en los que se corrobora la existencia de unas piezas denominadas «templazos» confeccionadas en telares horizontales de procedencia oriental y que fueron los responsables de que la industria textil andalusí se convirtiera en una de las más importantes del mundo (RODRÍGUEZ, 2012: 274). 
Telas construidas o cómo las palabras referidas a tejidos se instalan en el léxico...

trata, claro está, de telas ricas y lujosas. ${ }^{8}$

Ahora bien, y retomando la referencia anterior al espacio doméstico, habría que contemplar un hecho evidente, como es el que telas más humildes y sencillas tuvieran el mismo uso y funcionalidad que estos bellos ejemplares conservados hasta nuestros días. Es más, es imprescindible tener presente que el espacio doméstico en sí mismo es, sobre todo, multifuncional siendo una de sus principales características la escasez de mobiliario. Por lo tanto, en este contexto, los tejidos encuentran su verdadero protagonismo pudiéndose hablar, como ya ha sido definido en otro lugar, de «mobiliario textil» (SERRANO-NIZA, 2015: 311 y ss.). Esta denominación responde al hecho de que una buena parte de los enseres encontrados en las casas de esta época tenían en común el haber sido manufacturados a partir de una materia prima textil, bien fuese algodón, cáñamo, esparto, lana, lino o seda. Con esa materia prima se elaboraron los componentes del ajuar doméstico: alfombras, tapices, tapetes, colchones, cojines, cortinas, colchas, sábanas, etc... En definitiva, telas de diferentes texturas y colores que dan vida a la casa, calentándola, aislándola, decorándola, pero, también, construyendo espacios concretos.

Esta última imbricación con la arquitectura que tienen los tejidos es, precisamente, el denominador común de las casas tanto cristianas como islámicas de la península ibérica medieval.

Para comprobar este hecho, la mejor fuente a la que se puede recurrir, sin duda alguna, es la iconografía. Lamentablemente, para el estudio de las sociedades islámicas y cristianas en el período en el que este trabajo se instala, existe una clara descompensación, pues si bien el periodo gótico ha provisto de bellas imágenes a la historia del arte a través de las cuales podemos observar cómo eran esos espacios domésticos y cómo los objetos se distribuían en ellos, no ocurre lo mismo para las casas islámicas. ${ }^{9}$ En cualquier caso, y solo para hacernos una pequeña idea, podemos recurrir, por vía de ejemplo, a recientes trabajos que estudian un interior doméstico, bien sea islámico a través de las miniaturas que ilustran el Sulwān al-mutāa' (MAZzoli-GuiNTARD y ViguerA, 2019: 341-364), bien cristiano, mediante pinturas de la época (CABALLERO, 2019: 397-427).

En ambos estudios, las imágenes revelan interiores domésticos en los que las telas, ya sea puestas en el suelo, alfombrándolo, ya sea en las paredes, tapizándolas, aportan a la estancia color y textura. Asimismo, se pueden observar ciertas concomitancias en el «amueblamiento» puesto que no deja de ser curioso el cojín de brocado dorado que se acomoda sobre una alfombra extendida en lo que parece ser un estrado, ${ }^{10}$ según lo representa Pedro Berruguete en su obra

8 Por vía de ejemplo, las del Panteón Real de las Huelgas (Burgos), las colecciones del Real Monasterio de San Lorenzo de El Escorial, del Instituto Valencia de Don Juan o las del Museo Lázaro Galdiano.

9 Rachel ArIÉ (1966: 59) se lamentaba de la ausencia de fuentes iconográficas en las que apoyar una investigación rigurosa sobre la indumentaria islámica en Al-Ándalus. En efecto, la ausencia de imágenes islámicas que sirvan de soporte para el estudio de los términos aparecidos en los textos históricos o en la poesía, así como la somera descripción que se podía encontrar en ellos o en algunos diccionarios coetáneos se presenta como un reto para la investigación en la materia extrapolable a los interiores domésticos.

10 No obstante, algunos testimonios hacen referencia tanto a la importancia y uso del estrado como a su origen islámico. De hecho, el arabismo tarima significa «estrado», y proviene del andalusí taríma, «banco bajo», «lecho de madera» (CORRIENTE, 2003: 454-455). De la misma manera, un breve texto relativo a la venta de un inmueble pone de manifiesto que la tarima «no forma parte de la casa», por lo que el vendedor de esta puede llevarla consigo (LAGARDÈrE, 1995:162-163). 
denominada Los pretendientes de la Virgen, $h .1490 .{ }^{11}$ En este mismo escenario no es difícil imaginar otro momento cotidiano en el que las mujeres se acomoden en esos cojines dispuestos sobre la alfombra y compartan un momento de ocio y conversación, exactamente igual que el que recoge una de las miniaturas recién citada, la denominada Las dos favoritas del califa omeya Múāwiya (MAzzoliGuintaRd y Viguera, 2019: 358). Bien es verdad que ambas imágenes recogen interiores domésticos pertenecientes a familias privilegiadas, sin embargo, otras investigaciones cuyas respectivas documentaciones arrojan luz sobre estamentos sociales más humildes, no aportan datos diferentes. Es más, María Elena DíEz (2015:449), en uno de sus trabajos analiza las casas de la Alhambra tras su ocupación por los cristianos en 1492 y acomete un estudio comparativo con el fin de valorar «las pervivencias y cambios que derivados de la etapa medieval se mantuvieron o transformaron en la época moderna». En sus páginas (DíEz, 2015: 444), y con relación al ajuar, afirma que:

por lo general, exceptuando casas reales y señoriales, era un ajuar escaso y de fácil transporte. Los objetos de lujo no eran numerosos, primando lo funcional y con el fin de alcanzar un mínimo de habitabilidad. Este aspecto que se señala como algo propio del mundo islámico también caracterizó las casas de cristianos donde era más frecuente el ajuar textil -ropa de casa y ropa de vestir- que los muebles pesados.

En esta misma línea y partiendo de idéntico presupuesto, es decir, que el amueblamiento fundamental de una casa era textil, se podría decir que las habitaciones se llegaban a construir con telas, como lo demuestra la existencia de «alcándaras» en las paredes de las casas. Las «alcándaras» eran una especie de ganchos que, anclados a la pared, servían para sujetar en ellos telas que recorrían la estancia como si fuese un tabique y que, por tanto, permitía aislar espacios a modo de habitaciones (SERRANO-NIZA, 2019a: 138-141).

Por lo tanto, y partiendo de esta idea recién sugerida, en la que un tabique se levanta con una tela, se puede continuar construyendo esa habitación con diferentes textiles. Por ejemplo, para que recubran las paredes, suelos y techos $\mathrm{y}$, en este proceso imaginativo, añadir las texturas, los diseños y los colores propios de los tejidos, como puede verse en algunas reconstrucciones llevadas a cabo recientemente (SERRANO-NIZA, 2019a: 394). Además, este tipo de mobiliario textil participa de las características ya citadas anteriormente, su ligereza, su facilidad para el transporte, la versatilidad que proporcionaba la posibilidad de poner una habitación para dormir por la noche y convertirla en estancia para estar o trabajar durante el día. Todas ellas, características de las casas andalusíes que, pasado el tiempo y dada la estrecha convivencia y la transferencia cultural aludida anteriormente, quedan prendidas en las casas de la nueva sociedad cristiana. De hecho, será esa herencia la que le dé sus propias señas de identidad, pero no solo esto, puesto que, durante un largo periodo de tiempo, más o menos amplio dependiendo de la zona, la lengua castellana nombró con vocablos árabes su cotidianidad. Y, por tanto, en el léxico del espacio doméstico encontraremos un buen número de palabras cuyo origen árabe no deja lugar a dudas de ese intercambio de saberes y costumbres producido durante la Edad Media peninsular.

11 Retablo mayor de la iglesia de Santa Eulalia, Paredes de Nava, Palencia (CABAllero, 2019:424). 
Telas construidas o cómo las palabras referidas a tejidos se instalan en el léxico...

\section{NOMBRAR LOS ELEMENTOS DOMÉSTICOS CON PALABRAS DE ORIGEN ÁRABE}

Líneas arriba ya se ha aludido a que un «arabismo» es un vocablo de origen árabe que se ha introducido hasta formar parte de otra lengua. Este fenómeno, en sí mismo, comienza siendo lo que se denomina préstamo lingüístico, siendo un hecho común y reincidente entre lenguas en contacto, como las que convivieron en la península ibérica durante la Edad Media. Recuérdese a este efecto que, a partir del siglo viII, con la llegada de los árabes a ella, la península ibérica recibió el nombre de Al-Ándalus, cuyas fronteras se ampliaron y plegaron a lo largo de los siglos hasta la total desaparición, siendo el último reducto de presencia islámica el denominado reino nazarí de Granada. En este territorio peninsular no hubo ni unificación étnica, ni religiosa, ni cultural y, ni mucho menos, lingüística.

De hecho, un sucinto desbrozo de las lenguas de Al-Ándalus consistiría en, por un lado, delimitar qué lengua árabe se hablaba, dado que una característica inherente a este idioma es la diglosia, lo que significa que se usan simultáneamente dos variantes de la misma lengua. Una de ellas, de registro alto, denominada «árabe clásico» y cuyo cometido es ser la lengua administrativa del estado, al mismo tiempo que de la literatura y de la cultura en su sentido más amplio. Junto a esta lengua clásica y en perfecta convivencia se haya el árabe dialectal, la lengua de comunicación oral, presente en la vida cotidiana. Esta realidad lingüística del árabe desde sus comienzos hasta la actualidad existió, por lo tanto, en $\mathrm{Al}$ Ándalus. Sin embargo, en el caso andalusí se ha de hablar en sentido estricto de «haz dialectal andalusí» (CORRIENTE, 1977:6-7). Se trata de un complejo conjunto de dialectos que son resultado de dos circunstancias, los prestamos e interferencias tomados del sustrato autóctono, es decir, el romance, junto a los diferentes dialectos árabes que trajeron los musulmanes durante la conquista y posterior expansión de Al-Ândalus.

Igualmente, podría decirse que el panorama lingüístico en los primeros siglos tras la conquista era de bilingüismo, puesto que, junto al árabe, la lengua de la población musulmana, se hablaba la lengua romance autóctona. Si se considera el número de hablantes, los segundos eran muy superiores, pero, a pesar de esta descompensación, el árabe, según afirma CORRIENTE (1992:34)

ocupa claramente la situación dominante, como lengua ciudadana en una cultura netamente urbana y de las clases altas, cultas e integradas en la religión del estado, lo que relega el monolingüismo romance a los sectores rurales, pobres, incultos y cristianos, situación de la que naturalmente intenta salirse la mayoría de los afectados.

En este escenario, el papel de los denominados mozárabes, es decir, los cristianos que vivían en territorio islámico, será fundamental. De hecho «son los responsables de la importación de la lengua y cultura árabigo-islámica [...] a la Romania hispánica, y no la supuesta convivencia de las tres culturas» (CORRIENTE, 1998:338). La fascinación de estos cristianos por la lengua árabe queda recogida en un clásico texto de Álvaro de Córdoba (m.c.861) en su famoso Indiculus luminosus, escrito en 854, cuya queja se expresa de la siguiente manera:

¿no vemos que jóvenes cristianos, llenos de vida, de gallardía y de elocuencia, versados ya en la educación gentilicia y muy peritos en la lengua árabe, corren 
desatinados en pos de los libros de los caldeos; (...) y joh dolor! cristianos, ignoran su ley, y latinos, olvidan su propio idioma? De tal suerte, que apenas entre todos los cristianos se hallará uno entre mil que pueda razonablemente escribir a su hermano una carta familiar, y, por el contrario, hallaréis muchedumbre sin número que eruditamente declare la pompa de los vocablos.

En efecto, ese idioma de cuya pérdida se lamenta Álvaro de Córdoba debe ser la variedad romance hablada en al-Ándalus a la que Federico Corriente designa «romandalusí», consagrada en torno al siglo x y en máxima vigencia hasta los siglos XI- XII. ${ }^{12}$ En cambio, a partir de esa fecha, se expandirá con más fuerza el árabe andalusí que, robustecido como lengua de cultura, se propagó en una suerte de estandarización y mayor prestigio lingüístico. Esta situación lingüística se mantuvo, incluso, ya comenzada la conquista cristiana en la península ibérica y resulta curioso cómo se vuelve a producir un estado de bilingüismo inverso. Es decir, los mudéjares hablarán andalusí hasta que, paulatinamente, el romance hablado por los cristianos acabó imponiéndose.

De manera que tras una estrecha convivencia lingüística como la que se acaba de describir no resulta extraño que la lengua árabe se filtre a modo de huella histórica, si se quiere, en los entresijos de las lenguas romances peninsulares, como es el caso del castellano. Su acceso a esta lengua tiene, básicamente, dos vías: una directa, transmitidos por mozárabes, primero, y mudéjares, después y otra, indirecta, ocasionados, principalmente, por las traducciones. ${ }^{13}$ Por otra parte, existe un periodo favorecido en el que el mayor número de arabismos llegan al castellano, me refiero al siglo XIII; no será esto una coincidencia ya que es este el periodo en que existe una mayor estabilidad fronteriza entre cristianos y musulmanes. A este momento, se puede sumar, en menor medida y con muy distinta suerte, el denominado periodo morisco del siglo $\mathrm{XV}$, documentado en el trabajo de Juan MARTínEZ RuIz (1972) según la documentación procedente del Archivo de la Alhambra y que supone una prueba palpable del bilingüismo que caracterizó a los moriscos granadinos, como ya ha quedado dicho.

No será casualidad este hecho, ya que la lengua forma parte del proceso histórico y las páginas de la historia peninsular pueden añadir detalles concienzudamente precisos de todo ello, mientras que a la lingüística le compete observar los trazos conservados en el idioma, es decir, cómo se comunicaron los protagonistas, qué palabras utilizaron y cuáles sirvieron de ricos intercambios. Por todo ello, el estudio de los arabismos por campos léxicos aporta datos más que interesantes para el conocimiento de la vida cotidiana.

En efecto, el léxico de origen árabe penetra en campos muy concretos, pero todos ellos estrechamente vinculados a la vida cotidiana de su época, aunque, el campo semántico que tiene mayor interés para este trabajo es el que he denominado «la casa», entendiéndolo en un sentido muy amplio. Es decir, desde su misma construcción hasta los objetos que en ella existen, pues, sin duda

12 En sus propias palabras, «en los siglos XI y XII las bolsas de bilingüismo eran residuales» (CORRIENTE, 1992: 34).

13 Según LAPESA (1995:133) «Sumando el léxico propiamente dicho y los topónimos, no parece exagerado calcular un total superior a cuatro mil formas». Bien es verdad que la presencia del árabe es especialmente amplia en la toponimia y que estudios más exhaustivos de los arabismos harán disminuir considerablemente esa contabilidad, pues, excluyendo los topónimos, el vocabulario de origen árabe en el castellano solo alcanza a unas mil palabras, como queda recogido en obras más recientes (CORRIENTE, 2003 y 2018). 
Telas construidas o cómo las palabras referidas a tejidos se instalan en el léxico...

alguna, los arabismos se introdujeron hasta los rincones domésticos más íntimos, como lo demuestra la etimología de betamel y sus variantes betalmez, betalmé y betamé que procede del árabe, bayt al-ma' ('letrina') (GoROcH, 1949-1950:208-210). Como digo, muchas palabras relacionadas con la construcción fueron filtrándose hasta el incipiente castellano; algunas de ellas siguen vigentes, como, por ejemplo: adoquín, alicate, ataurique, azulejo, alféizar, ajimez o, incluso, albañil.

Otras, en cambio, no han llegado hasta nuestros días por diferentes razones, en la mayoría de los casos, extralingüísticas, hasta el punto de que se puede estimar una fecha histórica en la que los préstamos árabes dejaron de tener interés y esta tendrá lugar a partir del siglo $\mathrm{xV}$, excepto para la zona granadina, donde este hecho tardó algo más de tiempo en suceder, como queda demostrado con la documentación rescatada y editada por MARTínez Ruíz (1972:213-294). Recuérdese que, tras la unificación de la península ibérica por los Reyes Católicos, comienzan tiempos de cambios y renovación ideológica en los que el reino castellano va consolidando su expansión territorial, religiosa y cultural. Al mismo tiempo, esa época de transformación viene acompañada de sucesivas ordenanzas prohibiendo costumbres, ropas y el uso del árabe. En consecuencia, no sólo se dejan de introducir préstamos de la lengua árabe, sino que muchos de ellos, perfectamente consolidados en el castellano, son paulatinamente abandonados por otros términos de étimo latino. De esta manera, alfayate encontrará su equivalente en sastre, zaragüel será sustituido por pantalón y alarife será apartado en favor de maestro de obra. A ello se ha de sumar, como afirma Felipe Maíllo (1991: 505) que:

las palabras que denominaban objetos que adquirían uso por modas pasajeras o dependían de preferencias culturales, estaban sujetas a caer en desuso en un plazo de tiempo más o menos largo y ser reemplazadas por vocablos que nombraban los nuevos y cambiantes gustos culturales. Este es el caso específico de las prendas de vestir y los tejidos. ${ }^{14}$

Pero volvamos de nuevo al campo semántico al que he denominado «la casa». Vinculadas a esta amplia noción, tenemos palabras como zaguán, azotea, alcoba, alacena, tabique, algorfa, ajuar, alfiler, anafe, jofaina, alfombra, almohada, almadraque, alcatifa, alifafe y alhamar, entre otros. De hecho, de manera más específica, este amplio campo semántico puede dividirse en dos subcampos más especializados; por un lado, los elementos que forman parte de la construcción y por otro, los del ajuar. Los primeros de ellos realizados con materiales propios del gremio y los segundos fabricados mayoritariamente con textiles, como ha quedado demostrado en estudios anteriores sobre el amueblamiento en las casas medievales (SERRANONizA, 2015; 2019a y 2019b). La cuestión es, en qué momento, el campo conceptual de la arquitectura se cruza con el de los tejidos, transfiriéndose la denominación de un textil a un elemento arquitectónico y, por tanto, dando lugar a textiles construidos.

\section{TELAS CONSTRUIDAS: LA DURACIÓN DE LO TEMPORAL}

Decía Edward SAPIR (1977: 10) que «la lengua se mueve a lo largo del tiempo

14 Una trasformación que no se llevó a cabo de la misma manera en todas las lenguas romances puesto que en el portugués actual, siguen vigentes los términos, por ejemplo, «alfayate» $\mathrm{y}$ «almadraque». 
en una corriente de su propia hechura. Tiene un curso...nada es perfectamente estático». Esta afirmación que, sin duda, desvió los destinos de la lingüística, es de gran interés ahora para entender los cambios de significado que han afectado a un pequeño corpus de palabras que, designando textiles, se incorporarán como términos específicos al léxico de la arquitectura.

El procedimiento lingüístico por el que este fenómeno se produce está ampliamente descrito en los manuales de semántica puesto que es consustancial a la evolución de la lengua. De manera general, se puede denominar a este fenómeno como «cambio de significado» y la base de tal cambio se ha de buscar, sobre todo, en esa ductilidad que caracteriza al lenguaje y que hace que en la lengua nada sea estático, parafraseando las palabras ya citadas de SAPIR. En consecuencia, estos cambios de significados son hechos recurrentes en la lingüística y las causas por las que se producen, múltiples. Sin embargo, «muchos cambios, incluidos algunos que parecen falazmente simples, son debidos a causas excepcionales que solo cabe establecer reconstruyendo el fondo histórico completo» (ULMMAN, 1991 :222), siendo imprescindible atender a esa vieja y conocida relación que existe entre las palabras y las cosas. $\mathrm{Y}$, precisamente, para dar cuenta de esa relación, debe haber previamente un pacto de alianzas entre disciplinas, entre la historia y la lingüística, de cuya coalición se arroja luz a no pocas etimologías. ${ }^{15}$

Es decir, en el fenómeno del cambio semántico, no solo habrá causas lingüísticas, sino también causas históricas pues, con todo, la lengua suele ser mucho más conservadora que la propia cultura en la que nace, ya que no será difícil encontrar un buen número de objetos, incluso de conceptos, que irán cambiando con el tiempo, aunque en muchas ocasiones, el nombre que lo designa se mantendrá intacto. De hecho, y por más contradictorio que pudiera parecer, entre las numerosas causas por las que se produce un cambio semántico, además de lingüísticas, históricas y sociales, se encuentra «la exigencia de un nuevo nombre ${ }^{16}$ y es esta última razón la que resultará más que sugerente en el marco de estas páginas. Es más, cuando se requiere un nuevo nombre con el que designar, bien sea un objeto bien sea una idea nueva, la lengua tiene tres recursos concretos: a) con elementos que ya existen, forma la palabra nueva, b) toma un préstamo de un idioma extranjero y c) altera el significado de una vieja palabra.

Al mismo tiempo, se podría considerar que todos los arabismos que son objeto de investigación en este trabajo pueden proceder de la segunda de las opciones, la de tomar un préstamo. Es decir, fueron un préstamo cuando entraron en el castellano para designar un tejido o un elemento textil donde la lengua de entrada tenía enormes vacíos frente al número de objetos de esta índole que importaba. En esa línea tenemos, por vía de ejemplo, acitara, alcatifa o alicer. Ahora bien, una vez asentado el término y con el paso del tiempo, se producirá un nuevo cambio de significado y este se hará mediante el mecanismo propiciado por la metáfora. En

15 En este sentido, un clásico ejemplo es el del conocido bollo francés denominado croissant, cuyo significado, obviamente, tiene que ver con la luna creciente. $Y$ así concluiría su estudio etimológico si no interviniera la historia y enriqueciera su procedencia narrando cómo en Viena, a finales del siglo XVII, y para conmemorar la que fuese una victoria decisiva para derrocar a los turcos, se hicieron unos pastelillos en forma de luna creciente (emblema nacional de los turcos) y los llamaron hörnchen; después, los pasteleros franceses se limitaron a traducir la palabra alemana y de esta forma, el término croissant junto con el tipo de pastel al que nombra, se popularizó. Citado por UlmmanN, 1991: 223.

16 Una descripción detallada de las causas del cambio semántico, pueden encontrarse en UlLMANN, 1991: 222-238. 
Telas construidas o cómo las palabras referidas a tejidos se instalan en el léxico...

otras palabras, la metáfora será la responsable de que un objeto sea denominado con el nombre de otro, dada la semejanza que exista entre ambos.

Y será, a partir de aquí, desde donde se comenzará el relato mediante el que se podrá, reconstruir histórica y lingüísticamente, la manera en que los nombres de ciertos textiles pasan a denominar elementos arquitectónicos. Con este fin, considero que se debe poner el foco en las casas de moriscos, porque se podría decir, grosso modo, que representan una frontera de cultura material entre las casas de los musulmanes y las de los cristianos. Frontera que, si bien traía consigo un discurrir hacia la aculturación obligada, sin embargo «tuvo menos influencia en la arquitectura que otros aspectos de su cultura material y costumbres» (OriHuEla, 1996: 396). Unido a ello, una breve, pero interesante, descripción de las casas nazaríes y moriscas granadinas -bien sean conservadas, bien en restos arqueológicos- nos la proporciona Luis RAMÓN-LACA (2005: 126-127) de cuyo trabajo tomo esta cita: «traspasado el umbral es frecuente encontrar en el suelo un rectángulo con un pavimento más elaborado, con frecuencia vidriado, al que Torres Balbás denominó «almatraya» (...)concebida quizá para señalar a la vista la diferencia de nivel del suelo».

Igualmente, ORIHUELA (1996: 398) incluye el término almatraya dentro de las técnicas decorativas realizadas con alicatados y, así, entre ambas explicaciones se puede gestar una imagen de lo que este término representa. Más concreta resulta la definición en la que se especifica que se trata de un cuadrado hecho con azulejos en el pavimento delante de la puerta de las salas principales (NúÑEZ-GoNZÁLEZ, 2018:171).

Sin embargo, la ausencia del vocablo almatraya de los diccionarios, resulta ser una de las incógnitas más sugerentes a las que esta investigación se enfrenta. En efecto, el origen árabe del término parece fuera de dudas, tanto por su forma, que incorpora al lexema el característico artículo árabe al-, como por lo que representa, es decir, un tipo singular de pavimento característico de las casas nazaríes, primero y, después, de las moriscas. A pesar de ello, en ninguno de los rigurosos trabajos sobre arabismos dan cuenta de él y sólo en el Diccionario Histórico de la Lengua Española se localiza la palabra bajo el lema almadraja y se incluyen en él otras variantes a saber: almatraia y almadraxa, además de la ya citada almatraya. ${ }^{17}$ En su definición, aporta dos acepciones, la primera de ella indica que es «umbral de puerta o de ventana solado con azulejos», circunscrita dicha acepción a la zona andaluza; la segunda acepción señala que es «cuadro de azulejos en el pavimento». ${ }^{18}$ En cuanto a la documentación en la que se sustenta, los textos que apoyan la primera definición pertenecen al siglo XVI, en cambio, los de la segunda, se fechan en el siglo XVII.

De hecho, esta palabra supone un desafío tan arduo para la lingüística como para quien la maneje en el marco del estudio del espacio doméstico bajo las coordenadas que aquí se han ido trazando. Es más, la cuestión que cabe resolver con urgencia es, por un lado, averiguar cuál es el étimo de este vocablo y, por otro, si, el término tuvo en algún momento, el significado de un tipo de textil.

Desgraciadamente, a estas cuestiones las fuentes lexicográficas no ofrecen

17 Otra variante a este término no recogida en los diccionarios es almetralla, definida «en el centro del salón principal», «[referido al salón de Comares] hay un cuadro o almetralla de azulejos» (OLIVER HuRTADO 1875:269).

18 Diccionario Histórico de la Lengua Española (1960-1996) [en línea]. Disponible en: http://web.frl.es/ DH.html [Consulta: 24/06/2020]. En adelante, DHLE. 
respuesta alguna, razón por la que se hace necesario acudir a otra tipología de fuentes y localizar el nudo de la intersección en el que las diferentes informaciones se encuentran. En este sentido, retomo la sugerencia de RAMóN-LACA (2005:127) quien considera que la palabra almatraya comparte el étimo andalusí de almadraque, es decir, el vocablo árabe almațáh, nombre de lugar de la raíz ṬRH, que tiene el mismo significado (CORRIENTE, 2003:183 y DOZY y ENGELMANN, 1982:151). Es cierto que, tanto en árabe clásico como en andalusí, existió dentro del paradigma de nombres de lugar, uno que significaba «lugar (donde se tira algo)» siendo precisamente de ese étimo de donde procede un arabismo con múltiples variantes: almadraque, almadrá, almatrá, almatrac, matelàs, matalaf, madalá. A ello habrá que sumar sus variantes intrarromances, como señala Federico Corriente, tal como almadraqueja en castellano o almadraquexa y almatrixa en portugués (CORRIENTE, 2003:183). Obsérvese la proximidad entre estas variantes y las ya citadas, almadraja, almadraxa, almatraya y almatraia ${ }^{19}$ que el DHLE alberga.

Hay que añadir a esta información, algún dato más. La curiosa relación entre el arabismo «almadraque»y «atarraya», propiciada por esa raíz ṬRḤ que, como ya se ha dicho, en árabe significa 'tirar algo'. En origen, un almadraque o colchón, era un lugar donde echarse a dormir (Dozy y ENGELMANN, 1982:182). ${ }^{20}$ Por su parte, la palabra atarraya, procedente del mismo étimo, es un tipo de red que se usa para pescar (CORRIENTE, 2003: 239 y Dozy y ENGELMANN, 1982: 213-214) un «esparavel». A esto se añade un dato más, en relación con esta misma raíz. Esta vez vendrá suministrado por Pedro de Alcalá, autor de un valioso documento escrito hacia 1505 titulado Vocabulista arauigo, un diccionario que recoge el árabe dialectal granadino con sus equivalencias al castellano. Y es en esta obra en la que se haya el término tarịha, con el significado de «tarea en alguna obra» (PEZzI, 1989: 640) (ver tabla 1).

En resumen, no parece descabellado que la palabra almatraya tenga un étimo compartido con las palabras atarraya y almadraque y que, desde ese nexo común que resulta ser su étimo, haya habido un trasvase semántico producido entre los vocablos que significan 'colchón' o 'cojín', por un lado, y 'red', por otra, hasta confluir en el significado de 'pavimento extendido a modo de alfombra'. Es más, una de las características de las almatrayas es la disposición de los elementos que la componen, a menudo dispuestos en forma de red.

19 En el sur de Córdoba se registra una variante más, en la que parece haber intervenido la etimología popular, madrequeja, con el significado de colchoncillo en el que se acuestan los arrieros (GARULO, 1983:252).

20 Ver también la definición en DHLE [en línea]. Disponible en: http://web.frl.es/DH.html [Consulta: 24/06/2020]. 
Telas construidas o cómo las palabras referidas a tejidos se instalan en el léxico...

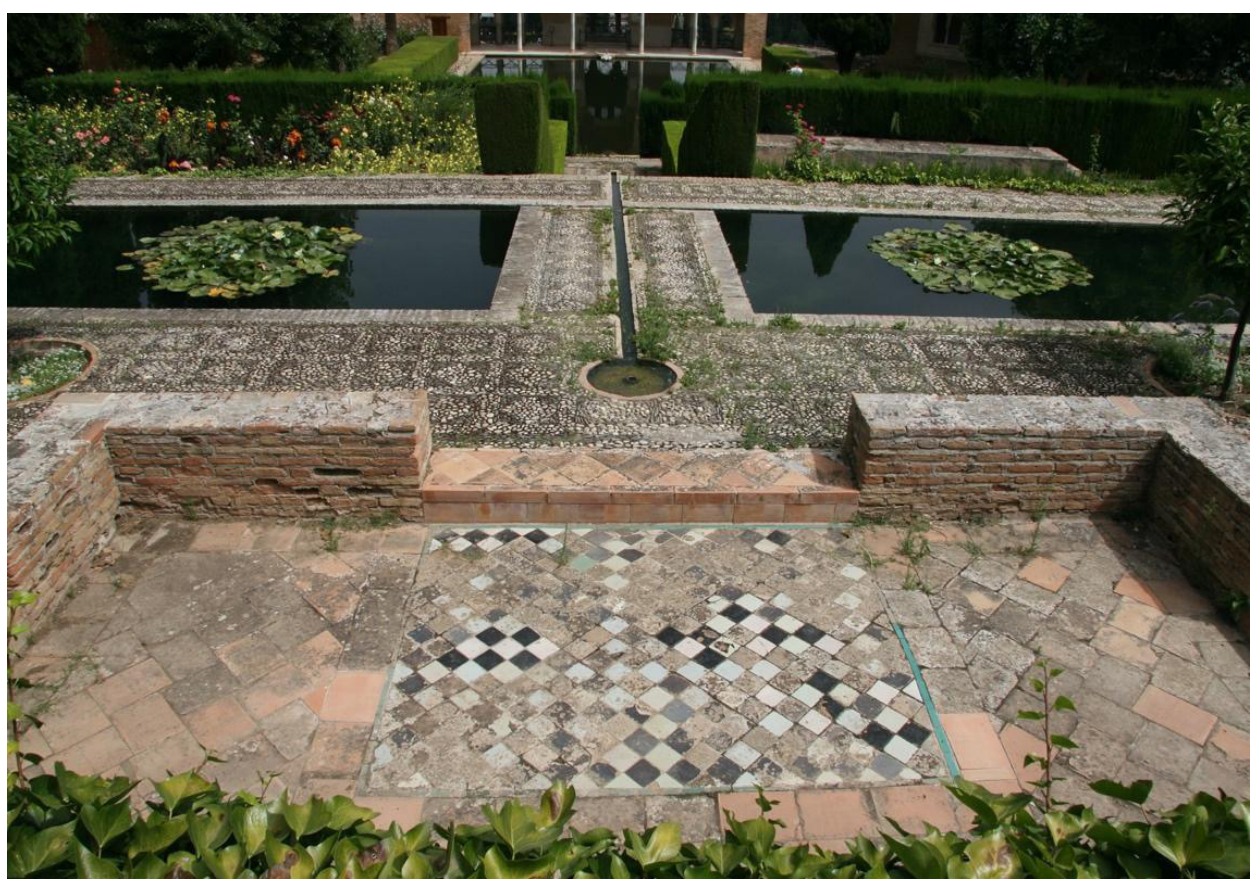

Figura 1. Almatraya en el Palacio del Partal. Pabellón Meridional.

La Alhambra de Granada. Foto: María Elena Díez Jorge.

Además, es necesario tener en cuenta que a veces los vocablos pueden presentar una cierta inestabilidad léxica, pero, al mismo tiempo, las palabras suelen quedar impregnadas en sus significados con viejos usos y costumbres. Me refiero a que, 'echar algo por el suelo', como se indica en la raíz del étimo aquí tratado, bien pudiera haber sido un simple textil, con funciones diferentes. Un tipo de alfombra que representa la entrada a una casa o a una de las dependencias principales, anunciando con ella, la importancia de esta. Una costumbre islámica que, con el devenir del tiempo y quizás solo vinculado al gremio de la construcción, fue transformada en una pieza con mayor durabilidad que el textil y con una finalidad más evidente, como la de «señalar a la vista la diferencia de nivel del suelo» (RAMÓN-LACA, 2005:127) y cuyo arabismo recuerda su origen.

Otra conocida palabra perteneciente al campo léxico de los tejidos que, sin embargo, acaba trasladándose al de la arquitectura es alcatifa. En este caso, el mismo Diccionario de la Lengua Española ya proporciona un doble significado, indicando que es tanto alfombra fina como la broza que se echa en el suelo previo a enlosarlo. ${ }^{21}$ Ahora bien, si retrocedemos en el tiempo dentro del marco de las fuentes lexicográficas, el diccionario de Covarrubias aporta una definición muy concreta ya que, citando a Francisco López Tamarid, revela que «alcatifa

21 Ver las acepciones $1^{\mathrm{a}}$ y $2^{\mathrm{a}}$, respectivamente, en Real Academia Española: Diccionario de la lengua española, 23. ${ }^{a}$ ed., [en línea, versión 23.3]. Disponible en: http://dle.rae.es/?id=1d4LS2b [Consulta: 24/06/2020]. En adelante DEL. 
es alhombra o suelo que se echa en el edificio»(COVArRuBiAs, 1987:75). Por lo tanto, será esta última definición la que nos deje apreciar el símil en el que se basa este trasvase de significado del que se viene hablando. Pero, volviendo al término alcatifa, las fuentes lexicográficas, en este caso, son muy generosas con su explicación. Encontramos tanto sus diferentes variantes, alquetifa y catifa, como su étimo en Corriente quien indica su origen andalusí alqațifa y este del árabe clásico, qatîfah con los respectivos significados de 'alfombra' y 'cobertor' (Corriente, 2003:137 y Dozy y ENGELMANN, 1982:88), a lo que Pedro de Alcalá añade un dato nuevo, que es «de terciopelo» (PEzzI, 1989: 676). Documentos casi contemporáneos a este último muestran la existencia de estos textiles entre los moriscos, y así se cita «una alcatifa de lana peluda», ${ }^{22}$ aportando, como puede comprobarse, una nueva noticia sobre este término. De manera que, como textil, estamos ante un tipo de alfombra que tanto podría haber sido de lana como de terciopelo y, probablemente de seda, aunque el rasgo que aquí predominará será esa característica de ser fina.

En cuanto a la manera en que el nombre de este textil pasa a engrosar los términos técnicos de la arquitectura será, de nuevo, un desafío científico al que se atenderá, principalmente, recorriendo fuentes lexicográficas históricas. En ese camino, un texto resulta revelador, pues en 1619 un autor anónimo recogía lo siguiente:

es condicion que sobre los pretales que estan puestos se a de entablar de cotanas rrecias que tengan dos dedos de grueso y desilados que junten muy bien y a de yr muy bien clavado con clabos de bellotes y se a de echar una alcatifa de casco y barro para que no se lebante el solado. ${ }^{23}$

Resulta esclarecedor que, en menos de un siglo, la palabra alcatifa transitara de nombrar un tipo de textil para nombrar un tipo de suelo, como así aparece recogido en los apeos sevillanos del siglo XVI: «en la cámara que corre sobre la caballeriza es este suelo de alcatifa» (NúÑ̃Z-GoNZÁLEZ, 2018: 577) (ver tabla 1).

Las razones de esta migración de significado o, en todo caso, de doble significado, habría que buscarla, en mi opinión, en la relación que pudiera existir entre el uso, textura, forma y color del tejido propiamente dicho con el del pavimento arquitectónico para que la metáfora que produce el cambio de significado llegara a buen término. Hasta donde se sabe, la alcatifa, según aparece nombrada en la documentación de la época, debió ser un textil elaborado en telar con diferentes materias primas (seda, algodón, lana o lino) cuyo resultado sería una tela recia con múltiples funciones, como cobertor en una cama, como alfombra en el suelo, con la que calentarse o calentar el espacio doméstico, como se indica en el siguiente documento: «Y en el tiempo frio es calentar las casas con mucha ropa, con mantas de pared, y alcatifas» (AviÑón, 1885, 17:43).

Por otro lado, sería de gran utilidad contar para este y otros casos semejantes, con fuentes iconográficas que colaboraran a comprender el factor que sirvió de conexión entre el textil y el pavimento, aunque desgraciadamente tengamos que contentarnos, de momento, con ilustraciones hipotéticas (SERRANO-NizA, 2019a: 378-379). En cualquier caso, se puede argumentar este cambio semántico

22 L-64-15, 9 de junio 1562, Níjar (Martínez Ruiz, 1972:45).

23 Real Academia Española: Banco de datos Corpus diacrónico del español (CORDE) [en línea]. Disponible en: http://corpus.rae.es/cgi-bin/crpsrvEx.dll [Consulta: 29/06/2020]. 
Telas construidas o cómo las palabras referidas a tejidos se instalan en el léxico...

considerando que la alcatifa, era una alfombra fina, cuya decoración, en muchos casos, fuese simplemente el color, aunque las hubo de gran valor económico, muchas veces superior al de una alfombra de nudo (SECO DE LUCENA, 1961:145). Su función de aislante unida a su aspecto recio, liso y, probablemente brillante, en el caso de seda, junto al alto valor económico que estas tuvieron, pueden haber sido los principios determinantes para que se produjera ese cambio de significado y su trasvase hacia el léxico de la arquitectura.

Otro de los controvertidos términos que, procedente del árabe, llegan al castellano con significados bien diferentes es alizar. En este caso, se refieren tanto a un tipo de textil, como a un friso de azulejos con los que se adornan la parte inferior de las habitaciones, e incluso, los mismos azulejos con los que se realiza este piso. Así al menos lo encontramos descrito en el DHLE, considerando que el étimo árabe es la palabra $i z \bar{a} r .{ }^{24}$ Asimismo, existe documentación en la que existe un término muy similar, alizer y alicer, con un significado también muy semejante, pues la única diferencia con «alizar» es que, en este caso, el zócalo es de yesería o está, simplemente, pintado (NúÑEZ-GóNZÁLEZ, 2020:601-602).

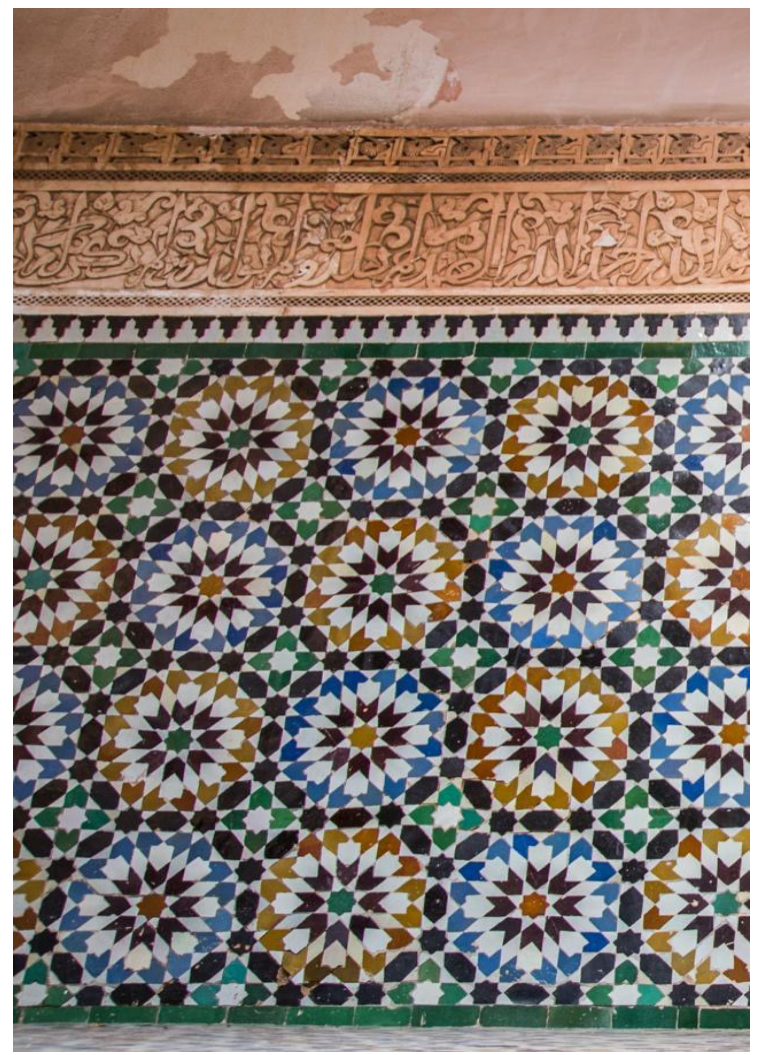

Figura 2. Alizar de azulejo (parte inferior) y alizar de yesería o alizer (parte superior) de una de las salas del Real Alcázar de Sevilla, año 2012. Foto: Dolores Serrano-Niza.

24 DHLE [en línea]. Disponible en: http://web.frl.es/DH.html [Consulta: 09/06/2020] 
Cierto es que resulta muy difícil entender la relación que pueda existir entre el término textil y el tecnicismo de la albañilería. El primero es, en árabe clásico, un tipo de lienzo, más o menos amplio, con el que envolverse o ceñir al cuerpo o a la cabeza, a modo de manto o toca, respectivamente. Una palabra emparentada con almaizar, esta ya sí convertida en arabismo y, por lo tanto, más conocida que suele ser interpretada como una 'toca morisca', ${ }^{25}$ aunque hay estudios que ya han ampliado las acepciones de este término e identificado con «sábana» (SERRANONizA, 2019a: 153-154). En cualquier caso, la metáfora que debía subyacer en este salto del léxico textil al de la arquitectura es casi imposible de encontrar a menos que, revisando la documentación etimológica, se encuentre un étimo diferente. Es el trabajo realizado por CORRIENTE (2003:178) quien advirtió un error cometido por autores anteriores, para quienes esta palabra derivaba del árabe andalusí aliḥ̣ár y éste a su vez del clásico iḥșār, lengua en la que significa 'constricción'. Y así es como figura actualmente en el Diccionario de la Lengua Española. ${ }^{26}$

En cambio, CORRIENTE (2003:178) propone que el étimo de la palabra alizar sea la palabra andalusí issál ('parte baja') y ésta del clásico asfal ('inferior') lo que resulta muy coherente con el significado de 'friso'. Es decir, se trata, desde la perspectiva lingüística, de una rearabización morisca de un arabismo que ya no se entendía. Aun así, hay que añadir que la palabra hașìr (muy similar al étimo propuesto por Covarrubias y Corominas para alizar) significa 'estera' (CORRIENTE, 1989: 178), y con ellas se cubrían las paredes desde el suelo hasta cierta altura, a modo de friso (ver tabla 1). En este sentido, y a modo de comparación, en muchas imágenes pictóricas medievales, pueden observarse un zócalo que rodea la pared de la habitación, como la conocida escena que representa el Nacimiento de la Virgen del Maestro de Marienlebens.

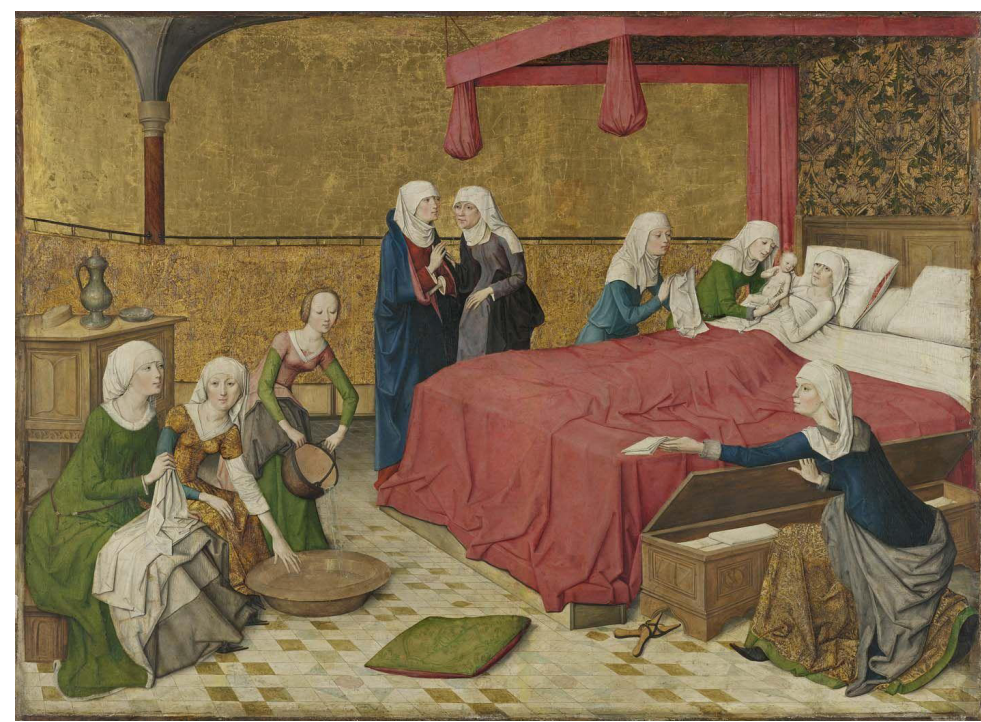

Figura 3. Meister des Marienlebens (Maestro de la vida de María). Nacimiento de la Virgen, h.147080. Munich, Pinacoteca Antigua.

25 DEL [en línea]. Disponible en: https://dle.rae.es/almaizar?m=form [Consulta: 09/06/2020] 26 DEL [en línea]. Disponible en: http://dle.rae.es/?id=1tqIaH8 [Consulta: 09/06/2020]. 
Telas construidas o cómo las palabras referidas a tejidos se instalan en el léxico...

En definitiva, se deja la puerta abierta a una nueva hipótesis de interpretación a la que otras fuentes y disciplinas puedan arrojar más luz de la que ahora los diccionarios proyectan. Me refiero, concretamente, a esa literatura científica que aporta información esencial para comprender el recorrido semántico que ciertos términos incorporan como, por ejemplo, los documentos sobre la cultura material o los usos y costumbres de la sociedad que habita el marco cronológico en el que este estudio se enmarca.

En otro orden de cosas, y ya que en líneas anteriores se ha hablado de las alcándaras, es pertinente traer ahora a colación otro tejido esencial cuyo nombre pasará a formar parte del léxico de la albañilería. Me refiero a la acitara o a algunas de sus muchas variantes: citara, çitar, sytar, çiter, çitera, çitare, çitaro) (CORRIENTE, 2003:89 y Dozy y ENGELMANN, 1982:38), cuyo étimo es el término andalusí assitára ('tapiz','cortina') y su significado, según el Diccionario de la Lengua Española es "paño de ornamento» así como "pared». ${ }^{27}$ Es decir, este vocablo se puede relacionar con estos dos significados básicos además del de 'cortina' (tabla 1).

No debe resultar difícil deducir la relación estrecha entre las «alcándaras»y estas «acitaras» ya que una de las formas más simples de conseguir una separación dentro de la misma estancia fue a través de unos ganchos y un textil. No sólo se crearon cobijos textiles para el lecho, a modo de dosel, sino que con idéntico sistema se habilitaban diferentes habitaciones (SERRANO-NiZA, 2019a: 138-142), pudiendo ser estas divisiones espaciales, además, reversibles. En este sentido, de nuevo la pintura podrá servir de aliada para ilustrar lo argumentado, tal y como puede comprobarse en la Anunciación $n^{28}$ de Stephan Lochner en la que una gran cortina que va desde el techo al suelo divide en dos el espacio representado.

Cabe suponer que, con el tiempo, esta segregación espacial se fue haciendo permanente y el textil dio lugar al ladrillo, aunque una parte del significado original se quedó prendido en el nuevo, ya que los tabiques con este nombre se caracterizan por ser poco gruesos, según se recogen en los apeos sevillanos: «esta pieza es dividida con una citara de un ladrillo» o «esta casapuerta está dividida con una acitara de medio ladrillo» (NúÑEZ-GONZÁLEZ, 2020:595).

\section{CONCLUSIONES}

Una de las causas del cambio de significado pudo haber sido el momento en que, por razones extralingüísticas, los arabismos empiezan a desaparecer del castellano. Es cierto que a esta lengua habían llegado para nombrar nuevos objetos u otros no tan nuevos pero que, vinculados a la cultura árabe, se ponían de moda entre los cristianos; sin embargo, apremiados por las circunstancias históricas y cambio de mentalidad, esas palabras de origen árabe, y quizás el objeto al que nombraron, comenzaron a desaparecer. Esto no significa que un puñado de ellos, como los que aquí se han visto, consiguieran sobrevivir conservando presencia y una parte de su significado, aunque, eso sí, fuera de la lengua común y relegados al vocabulario específico de la construcción arquitectónica.

Por otra parte, el hecho de que, en ocasiones, la búsqueda del étimo sea

$273^{\mathrm{a}} \mathrm{y} 2^{\mathrm{a}}$ acepción respectivamente en el DEL [en línea]. Disponible en: http:// dle.rae.es/?id=0UJTGH9 [Consulta: 22/06/2020].

28 Catedral de Colonia (h. 1440). Colonia, Museo Wallraf-Richartz. 
controvertida, puede documentar los cambios lingüísticos que se produjeron en este periodo de tiempo. Es el caso, por ejemplo, del término «alizar» al que las fuentes durante años dieron un étimo equivocado hasta el hallazgo del que parece ser cierto, demostrándose que se produjo, en un momento determinado, una rearabización de una palabra usada por los moriscos que apenas ya sí se entendía.

Pero, más allá de las cuestiones puramente lingüísticas, lo que prevalece en esta crónica del trasvase de un vocabulario textil hasta el léxico de la arquitectura es la realidad patente de que las telas se usaron como revestimientos y como tabiques y que esos textiles fueron convertidos en algo menos efímero al construirlos de albañilería. Además, las metáforas subyacentes en estos cambios de significado arrojan luz sobre el valor que ciertos objetos tenían en estas sociedades en pleno albor de la Edad Moderna y, en cualquier caso, el hecho de que estos cambios de significados se produjeran entre los siglos XV y XVI dan cuenta del período histórico que se estaba viviendo, un momento de pérdidas tanto de usos y costumbres, que ya se consideran anticuadas, como de las palabras que las nombraban.

TABLA 1

Sinopsis de la evolución de los términos analizados

\begin{tabular}{|c|c|c|c|c|}
\hline Lema & Variantes & $\begin{array}{l}\text { Étimo árabe } \\
\text { significado }\end{array}$ & $\begin{array}{l}\text { Significado } \\
\text { como textil }\end{array}$ & $\begin{array}{l}\text { Signific a do } \\
\text { como elemento } \\
\text { arquitectónico } \\
\text { (ss. XV-xvI) }\end{array}$ \\
\hline almatraya & $\begin{array}{l}\text { almatraia, almadraxa, } \\
\text { almetralla }\end{array}$ & $\begin{array}{l}\text { almatráh ('lugar donde se } \\
\text { tira algo') }\end{array}$ & $\begin{array}{l}\text { Pieza textil } \\
\text { gruesa, útil para } \\
\text { dormir sobre } \\
\text { ella en el suelo } \\
\text { o puesta sobre la } \\
\text { cama, haciendo } \\
\text { las veces de } \\
\text { colchoncillo }\end{array}$ & $\begin{array}{l}\mathrm{C} \text { u a d r a d o } \\
\text { formado por } \\
\text { azulejos en } \\
\text { el pavimento } \\
\text { delante de } \\
\text { habitaciones o } \\
\text { salas principales }\end{array}$ \\
\hline alcatifa & alquetifa, catifa & $\begin{array}{l}\text { alqatífa } \\
\text { ('alfombra','cobertor') }\end{array}$ & Alfombra fina & $\begin{array}{l}\text { Broza para } \\
\text { allanar el suelo. } \\
\text { Tipo de solería }\end{array}$ \\
\hline \multirow[t]{3}{*}{ alizar } & \multirow[t]{3}{*}{ alicer,alicer, aliçar } & $\begin{array}{l}\text { izār: «tipo de lienzo». } \\
\text { (DHLE) }\end{array}$ & \multirow[t]{3}{*}{$\begin{array}{l}\text { Tipo de lienzo/ } \\
\text { Estera }\end{array}$} & \multirow[t]{3}{*}{$\begin{array}{l}\text { Friso } \\
\text { azulejos }\end{array}$} \\
\hline & & $\begin{array}{l}\text { aliḥsár: 'constricción' } \\
\text { (Corriente) }\end{array}$ & & \\
\hline & & $\begin{array}{l}\text { issál ('parte baja') } \\
\text { (Corriente) }\end{array}$ & & \\
\hline alizer & alizer,alicer & Mismo étimo que alizar & $\begin{array}{l}\mathrm{M} \text { i } \mathrm{s} \quad \mathrm{m} \text { o } \\
\text { significado que } \\
\text { alizar }\end{array}$ & $\begin{array}{l}\text { Friso pintado o } \\
\text { de yesería }\end{array}$ \\
\hline
\end{tabular}


Telas construidas o cómo las palabras referidas a tejidos se instalan en el léxico...

\begin{tabular}{|l|l|l|l|l|}
\hline acitara & $\begin{array}{l}\text { cítara, çitar, sytar, } \\
\text { çiter, çitera, çitare, } \\
\text { çitaro }\end{array}$ & Assitára ('tapiz', 'cortina') & Cortina & $\begin{array}{l}\text { T a b i q u e } \\
\text { delgado }\end{array}$ \\
\hline
\end{tabular}

Elaboración propia.

\section{REFERENCIAS}

Arié, R. (1966): «Le costume des musulmans de Castille au XIIIe siècle d'après les miniatures du Libro del Ajedrez», Melanges de la Casa de Velázquez, 2: 59-69.

AppaduraI, A. (1986): "Introduction: commodities and the politics of value» en Appadurai (ed.), The Social Life of Things. Commodities in Cultural Perspective, Cambridge University Press, Cambridge.

Aviñón, J. de, (1885): Sevillana Medicina, Sociedad de Bibliófilos Andaluces, Sevilla.

Caballero Escamilla, S. (2019): «Lugares donde disfrutar, morar y rezar. La diversidad del ámbito doméstico en el tardogótico hispano», en M.E. Díez Jorge (ed.), De puertas para adentro. La casa en los siglos XV-XVI, Comares, Granada: 397-427.

CORRIENTE, F. (1977): A gramatical Sketch of the Spanish Arabic Dialect Bundle, Instituto Hispano-Árabe de Cultura, Madrid.

Corriente, F. (1989): El léxico árabe andalusí según el "Vocabulista in Arábico», Departamento de Estudios Árabes e Islámicos, 2. Universidad Complutense, Madrid.

Corriente, F. (1992): Árabe andalusí y lenguas romances, Editorial Mapfre, Madrid.

Corriente, F. (1998): Poesía dialectal árabe y romance en Alandalús, Gredos, Madrid.

CORRIENTE, F. (2003): Diccionario de arabismos y voces afines en iberorromance, Gredos, Madrid.

CORRIENTE, F. (2018): Dictionnaire des emprunts à l'arabe dans les langues romaines occidentales (castillian, portugais et galicien, catalán, français et italien et les dialectes mineurs), Gruyter, Berlín.

Covarrubias Orozco, S. de (1987): Tesoro de la Lengua castellana, Editorial Alta Fulla, Barcelona.

Díez Jorge, M.E. (2015): «Casas en la Alhambra después de la conquista cristiana (1492-1516: pervivencias medievales y cambios», en M.E. Díez y J. NAVARRO (eds.), La casa medieval en la península ibérica, Sílex, Madrid: 395-463.

Dozy, R.; ENGELMANN, W. (1982): Glossaire des mots espagnols et portugais dérivés de l'arabe, Apa-Oriental Express, Amsterdam.

Dozy, R. (1845): Dictionnaire détaillé des noms des vêtements chez les arabes J.Muller, Amsterdam.

Garulo Muñoz, T. Dozy, R.; Engelmann, W. (1983): Los arabismos en el Léxico andaluz (según los datos del Atlas Lingüístico y Etnográfico de Andalucía), Diputación de Córdoba-Instituto- Hispano árabe de cultura, Madrid.

González Marrero, M.C. (2014): «Tejidos, vestidos y modas. El gusto por lo extranjero en la Casa y en la Corte de Isabel la Católica», en Los gustos y la moda a lo largo de la historia, Universidad de Valladolid, Valladolid: 15-74.

Goroch, M. (1949-1950): «Una etimología árabe: betamel, metalmez, betalmé, betamé», Studia Neophilologica, 22: 208-210. 
LAGARDÈRe, V. (1995): Histoire et société en Occident musulman au Moyen Âge. Analyse du Mi yār d'Al-wanšarìsì, Consejo Superior de Investigaciones Científicas, Madrid.

LAPESA, R. (1995): Historia de la lengua española, Gredos, Madrid.

LOMBARD, M. (1978): Les textiles dans le monde musulman, VIIe-XIIe siécle, Mouton Éditeur, Paris-La Haya-New York.

Maíllo Salgado, F. (1991): Los arabismos del castellano en la baja Edad Media, Universidad de Salamanca, Salamanca.

MArtínez, M. (2012): «Influencias islámicas en la indumentaria medieval española», Estudios sobre patrimonio, cultura y ciencias medievales, 13-14: 187-222.

Martínez Rodríguez, M.A. (2019): «Los textiles: fuentes de diseño plano en la arquitectura novohispana», en R. J. Payo Hernándz, E. Martín Martínez de Simón, J. MATESANZ del BarRio y M.J. ZaPARAín YÁÑEZ, Vestir la arquitectura. XXII Congreso nacional de historia del arte, Universidad de Burgos, Burgos: 177-182.

Martínez Ruíz, J. (1972): Inventarios de bienes moriscos del reino de Granada (siglo XVI), Consejo Superior de Investigaciones Científicas, Madrid.

Mazzoli-Guintard, C.; Viguera Molins, M.J. (2019): «La casa en las miniaturas del Sulwān al-muțā' (Manuscrito de El Escorial número 528, s. XVI)», en M.E. DíeZ (ed.), De puertas para adentro. La casa en los siglos XV-XVI, Comares, Granada: 341-364.

Moreno Díaz del Castillo, F.J. (2015): «El hogar morisco: familia, transmisión patrimonial y cauce de asimilación», Al-Kurras. Cuaderno de estudios mudéjares y moriscos, 1: 97-119.

NúÑEZ-GonZÁLEZ, M. (2018): «Domestic architecture in 16th century Seville: San Salvador», VLC arquitectura, 5/ 2: 159-173.

Núñez-GonzÁlez, M. (2020): Arquitectura, dibujo y léxico de alarifes en la Sevilla del siglo XVI, Universidad de Sevilla. Sevilla.

Olivares Martínez, D. (2019): «Del terciopelo a la piedra: tejidos simulados, heráldica y memoria en el colegio de San Gregorio de Valladolid», en R. J. Payo Hernándz, E. Martín Martínez de Simón, J. Matesanz del Barrio y M.J. ZAPARAín YÁÑEZ, Vestir la arquitectura. XXII Congreso nacional de historia del arte. Universidad de Burgos, Burgos: 101-107.

Oliver Hurtado, J.M. (1875): Granada y sus monumentos árabes, Málaga.

Orinuela, A. (1996) «Técnicas constructivas en la arquitectura doméstica de los moriscos granadinos», en Actas del I Congreso Nacional de Historia de la Construcción, CEHOPU, Madrid: 395-398.

Payo Hernándz, R. J.; Martín Martínez de Simón, E.; Matesanz del Barrio, J.; Zaparaín YÁÑEZ, M.J. (2019): Vestir la arquitectura. XXII Congreso nacional de historia del arte. Universidad de Burgos, Burgos

Pezzi, E. (1989): El vocabulario de Pedro de Alcalá, Editorial Cajal, Almería.

RAMÓN-LACA MenÉndeZ DE LuARCA, L. (2005): «El hogar morisco», Oppidum, 1: 121142.

Rodríguez Peinado, L. (2012): «La producción textil en al-Andalus: origen y desarrollo», Anales de Historia del Arte, 22, núm. Especial (II): 265-279.

Rodríguez Peinado, L. (2019): «Tejiendo el muro: imágenes y ornato», en R. J. Payo Hernándz, E. Martín Martínez de Simón, J. Matesanz del Barrio y M.J. ZAPARAín YÁÑEZ, Vestir la arquitectura. XXII Congreso nacional de historia del arte, Universidad de Burgos, Burgos: 108-112.

RuIz SouzA, J.C. (2014): «Las telas ricas en la arquitectura. La permanencia de lo 
efímero», Anales de Historia del Arte, 24: 497-516.

Ruiz SouzA, J.C. (2019): «Arquitectura o telares de yeso. De las Huelgas de Burgos a la Alhambra de Granada. Ss. XIII-XIV», en R. J. PAYo HernándZ, E. MARTín Martínez de Simón, J. Matesanz del Barrio y M.J. Zaparaín Yáñez, Vestir la arquitectura. XXII Congreso nacional de historia del arte. Universidad de Burgos, Burgos: 760-764.

dos Guimaraes SÁ, I. (2013): «Habitar: del espacio a los objetos», en M. García (dir.), Cultura material y vida cotidiana moderna: escenarios, Sílex, Madrid: 113130.

SALADRIGAS CHENG, S. (1996): «Los tejidos en al-Andalus: siglos IX-XVI. Aproximación técnica», en España y Portugal en las rutas de la seda. Diez siglos de producción y comercio entre Oriente y Occidente, Universidad de Barcelona, Barcelona: 74-98.

SAPIR, E. (1977): El lenguaje. Introducción al estudio del habla, Fondo de Cultura económica, México, Buenos Aires.

Seco de Lucena Paredes, L. (1961): Documentos Árabes Granadinos, Instituto de Estudios Islámicos, Madrid.

SERrano-NizA, D. (2015): «Amueblar la casa con palabras. Fuentes lexicográficas árabes para el estudio del ámbito doméstico», en M.E. DíEz y J. NAVARro (eds.), La casa medieval en la península ibérica, Sílex, Madrid: 307-336.

SERrANo-NizA, D. (2019a): «Textiles para el sueño. Ropa y ajuar morisco para hacer una cama», en D. SERRANo-Niza (ed.) Vestir la casa. Objetos y emociones en el hogar andalusí y morisco, CSIC, Madrid: 27-158.

SERrANO-NizA, D. (2019b): «Una habitación con telas. El mobiliario textil de origen andalusí en una casa morisca», en M. E. DíEz Jorge (ed.), De puertas para adentro. La casa en los siglos XV-XVI, Comares, Granada: 365-394.

SimONET, F.J. (1983): Historia de los mozárabes de España, t.2 (de Abderramán I a Mohamed I (años 756 a 870), Ediciones Turner, Madrid.

Steiger, A. (1967): «Arabismos», en Enciclopedia Lingüística Hispánica, Madrid, CSIC, tomo II: 93-126.

UllmanN, S. (1991) Semántica. Introducción a la ciencia del significado, Taurus Ediciones, Madrid.

ZARAgoza Bernal, J.M. (2015): «Ampliar el marco. Hacia una historia material de las emociones», Vínculos de Historia, 4: 28-40. 